\title{
Studi Spasial Kejadian Malaria Serta Pengaruh Kepadatan Plasmodium sp. Terhadap Anemia Dan Trombositopniapada Penderita Malaria Di Kabupaten Kepulauan Talaud
}

\section{Study of Spatial Incidence of Malaria and the Effect of Density of Plasmodium sp. Against Anemia and Thrombocytopenia in Malaria Patients In Talaud Islands Regency}

\author{
Pitreyadi Johanis Jusuf Sadukhb, Joy Victor Imanuel Sambuagac, Bongakaraengd \\ aJurusan Kesehatan Lingkungan Poltekkes Kemenkes Kupang, Indonesia \\ ${ }_{b, c}$ Jurusan Kesehatan Lingkungan Poltekkes Kemenkes Manado, Indonesia
}

\section{A B S T R A C T / A B S T RA K}

Malaria affects almost all components of the blood, and thrombocytopenia is one of the haematological abnormalities encountered and has received much attention in the scientific literature. Plasmodium infection can cause abnormalities in the structure and function of platelets. This study aims to spatialize/map the spread of malaria events, locations and physical and chemical environmental conditions of breeding places of malaria vectors and analyze the effect of Plasmodium sp density on anaemia and thrombocytopenia in malaria sufferers in Talaud Islands Regency in 2018. The research sample was malaria sufferers in April. Until August, who came to check at the Community Health Center in Talaud Islands Regency to obtain data on Plasmodium sp density, anaemia and thrombocytopenia, then coordinate data on the homes of malaria sufferers and Anopheles sp habitat and the physical and chemical environmental conditions of Anopheles sp habitat that were surveyed using tools Global Positioning System (GPS) is processed using the help of Arcgis 9.3 program. To analyze the effect of plasmodium sp density on anaemia and thrombocytopenia using Chi-square test statistics. The results of the study The spread of malaria incidence and the distance of Anopheles sp habitat with malaria sufferers' homes in Talaud Islands Regency in 2018 were spelt out. Physical environmental conditions (temperature and humidity) and chemical environment ( $\mathrm{HH}$ and salinity) in the habitat of Anopheles sp. in residential areas of malaria sufferers are Temperature 27.9 - 29.8 0c, humidity $70.5 \%$ $80.4 \%$, pH in the range $5.6-8.1$ and salinity $0.04-1.35 \%$. The density of Plasmodium $\mathrm{sp}$ in 34 malaria sufferers consisted of 18 cases,+ 10 cases,++ 5 cases +++ and 1 case ++++ . Statistical test results have a relationship between Plasmodium sp density against anaemia and thrombocytopenia in malaria sufferers in Talaud Islands District in 2018.

Keywords: Spatial, Malaria; Anemi; Thrombocytopenia.

Malaria mempengaruhi hampir semua komponen darah, dan trombositopenia merupakan salah satu kelainan hematologis yang ditemui, dan banyak mendapat perhatian di literature ilmiah. Infeksi Plasmodium dapat menyebabkan abnormalitas pada struktur dan fungsi trombosit. Penelitian ini bertujuan untuk menspasialkan/memetakan penyebaran kejadian malaria, lokasi dan kondisi lingkungan fisik dan kimia breeding places vektor malaria dan menganalisa pengaruh kepadatan Plasmodium sp terhadap Anemia dan Trombositopenia pada penderita malaria Di Kabupaten Kepulauan Talaud Tahun 2018. Sampel penelitian yaitu Penderita malaria pada bulan April sampai bulan Agustus yang datang memeriksakan diri di Puskesmas yang ada Di Kabupaten Kepulauan Talaud untuk didapatkan data kepadatan Plasmodium sp, anemia dan trombositopenia, kemudian data titik koordinat rumah penderita malaria dan habitat Anopheles sp serta kondisi lingkungan fisik dan kimia 
habitat Anopheles sp yang disurvei menggunakan alat Global Positioning System (GPS) diolah dengan menggunakan bantuan program Arcgis 9.3. Untuk menganalisa pengaruh densitas plasmodium sp terhadap anemia dan trombositopenia menggunakan statistik uji Chi square. Hasil penelitian Penyebaran kejadian malaria dan Jarak habitat Anopheles sp dengan rumah penderita malaria di Kabupaten Kepulauan Talaud Tahun 2018 terspasialkan. Kondisi lingkungan fisik (Suhu dan kelembaban) serta lingkungan kimia (pH dan Salinitas) pada habitat Anopheles sp. di daerah pemukiman penderita malaria adalah Suhu 27.9 - 29.8 oc, kelembaban 70.5\% - 80.4\%, pH berada di kisaran 5.6 - 8.1 dan salinitas $0.04-1.35 \%$. Densitas Plasmodium sp pada 34 penderita malaria terdiri dari 18 kasus +, 10 kasus ++, 5 kasus +++ dan 1 kasus ++++. Hasil uji statistik ada hubungan antara kepadatan Plasmodium sp terhadap anemia dan trombositopenia pada penderita malaria di Di Kabupaten Kepulauan Talaud Tahun 2018.

Kata kunci :Spasial; Kejadian Malaria; Anemia; Trombositopenia.

Copyright (C) 2020 Jurnal Kesehatan Lingkungan All right reserved

Alamat korespondensi email :s.pitreyadi@yahoo.com

\section{PENDAHULUAN}

Indonesia merupakan salah satu negara yang masih terjadi transmisi malaria (berisiko malaria atau risk malaria), dimana pada tahun 2017 Annual Paracite Incidence (API) sebesar 0,99 per 1000 penduduk berisiko (Kemenkes RI, 2018).

Bila dilihat data kasus malaria per provinsi pada tahun 2017, provinsi dengan angka API tertinggi adalah Papua, Papua Barat dan Nusa Tenggara Timur. Sementara Provinsi Sulawesi Utara berada pada urutan kesembilan dari 34 Provinsi di Indonesia dengan angka API 0,37 per 1000 penduduk berisiko (Kemenkes RI, 2018).

Penyakit malaria masih merupakan masalah kesehatan di Provinsi Sulawesi Utara, ini ditandai dengan banyaknya kasus klinis dan positif malaria dibeberapa kabupaten yang ada di Provinsi Sulawesi Utara khususnya daerah kepulauan, daerah terpencil yang jauh dari pusat pelayanan kesehatan.Tahun 2016 dari 24.440 sediaan darah yang diperikasa, terdapat 1.838 kasus malaria positif. (DinkesdaProv. Sulut, 2017)

Kabupaten Kepulauan Talaud merupakan salah satu Kabupaten di
Provinsi Sulawesi Utara dengan tingkat endemisitas malaria yang tinggi, dimana pada tahun 2016 Kabupaten Kepulauan Talaud menempati urutan ketiga angka jumlah kasus tertinggi dari 15 Kabupaten atau Kota di Provinsi Sulawesi Utara setelah Kabupaten Kepulauan Sangihe dan Kabupaten Minahasa Tenggara. (DinkesdaProv. Sulut, 2017). Menurut Riskesdas tahun 2013 Insiden malaria di Sulawesi Utara dengan diagnosa sebesar 2,7 \% dan prevalensi 10,0\%. Berdasarkan sumber yang sama Insiden Malaria di Kepulauan Talaud 9,3 \% dan prevalensi $10,0 \%$. Berdasarkan sumber yang sama Insiden malaria di Kepulauan Talaud 9,3 $\%$ dan prevalensi sebesar 36,7 \% dari jumlah itu hanya 8,7 penderita memperoleh pengobatan dengan obat program. (Kemenkes RI, 2013)

Secara umum kondisi geografis Kabupaten Kepulauan Talaud memiliki dataran dengan banyak bukit, terdapat kolam ikan, muara-muara sungai, rawa dan laguna. Dilihat dari kondisi geografis Kabupaten Kepulauan Talaud sangat 
dimungkinkan untuk menjadi tempat perkembangbiakan nyamuk Anopheles sp.

Malaria mempengaruhi hampir semua komponen darah, dan trombositopenia merupakan salah satu kelainan hematologis. Infeksi Plasmodium dapat menyebabkan abnormalitas pada struktur dan fungsi trombosit. Beberapa mekanisme yang dipostulasikan sebagai penyebab trombositopenia diantaranya lisis dimediasi imun, sekuestrasi pada limpa dan gangguan pada sumsum tulang (Ansari dkk, 2009).

Penelitian yang dilakukan Jojera dkk (2013), pada 135 pasien yang positif malaria di Gujarat, India didapat hasil $89,62 \%$ pasien mengalami penurunan jumlah trombosit. Trombositopenia merupakan temuan hematologi yang umum pada malaria dan sering dijadikan sebagai indikator malaria di daerah endemik.

Di Indonesia masih menilai kadar hemoglobin sebagai indikator malaria berat, padahal infeksi Plasmodium juga mempengaruhi kadar trombosit dalam darah tepi, dan berhubungan dengan patogenesis malaria berat (Natalia, 2014).

Lingkungan fisik dan kimia air habitat perindukan diduga mempengaruhi laju perkembangbiakan jentik Anopheles. Semakin tinggi konsentrasi $\mathrm{CO}_{2}$ air, semakin banyak ion $\mathrm{H}_{+}$dihasilkan hingga $\mathrm{pH}$ cenderung menurun. $\mathrm{pH}$ yang melebihi 10 menyebabkan mikroorganisme tidak berkembang dengan baik. Selain itu jentik Anopheles tidak dapat hidup dengan baik pada suhu ekstrim tinggi yang disebut "thermal death point", karena dengan bertambah tinggi suhu perkembangan larva semakin cepat disamping itu juga dapat menyebabkan kematian. (Ishak, dkk 2009)

Pemetaan suatu wilayah sering menggunakan Sistem informasi geografis (SIG) merupakan sistem bebasis komputerisasi yang memiliki kemampuan mengelola data seperti pengumpulan, penyimpanan, pengolahan, analisis, pemodelan dan penyajian data spasial (keruangan) yang terkait pada lokasi di permukaan bumi. Dengan memanfaatkan teknologi SIG yang dipadu dengan teknologi penginderaan jarak jauh (inderaja), dapat membuahkan informasi spasial dengan tiga komponen yaitu, data lokasi, non lokasi dan dimensi waktu yang dapat memberikan informasi perubahan dari waktu ke waktu (Soenarmo, 2009).

Sistem informasi geografis adalah sebuah sistem untuk pengelolaan, penyimpanan, pemrosesan, analisis dan penayangan (display) data yang terkait dengan permukaan bumi. Untuk dapat beroperasi, sistem ini membutuhkan perangkat keras (hardware) dan perangkat lunak (software) juga sumber daya manusia yang mengoperasikannya (brainware) (Soenarmo, 2009). Elemenelemen tersebut bergabung dengan cara tertentu untuk selanjutnya mentransformasikan informasi agar menjadi informasi yang berguna, data perlu diolah melalui sebuah siklus. Siklus ini disebut siklus pengolahan data (Danoedoro, 2004)

\section{METODE}

Jenis penelitian adalah analitik dengan rancangan cross-sectional, untuk melihat Pengaruh Kepadatan Plasmodium sp terhadap anemia dan trombositopenia pada penderita malaria di Kabupaten Kepulauan Talaud.

Populasi penelitian adalah Penderita malaria di Kabupaten Kepulauan Talaud pada bulan April sampai bulan Agustus tahun 2018. Sampel ditentukan secara Accidental Sampling yaitu Penderita malaria pada bulan April sampai bulan Agustus yang datang memeriksakan diri pada 5 wilayah kerja Puskesmas (Beo, 
Rainis, Tule Lirung Dan Damau) yang berjumlah 34 penderita.

Pemetaan penyebaran kasus malaria dilakukan dengan observasi seluruh rumah kasus yang yang dijadikan subyek penelitian. pengambilan koordinat rumah kasus malaria yang positif Plasmodium berdasarkan pemeriksaan sediaan darah.

Pemetaan jarak habitat larva nyamuk Anopheles sp dilakukan dengan cara tracking menggunakan GPS pada semua habitat larva Anopheles dilokasi penelitian. Membuat buffer kasus dan habitat menggunakan aplikasi Arc.GIS versi 9.3. Menurut Boewono dan Ristiyanto (2004) jarak antara tempat habitat larva dan rumah kasus malaria dibagi menjadi 3 (tiga) zona, yaitu antara lain:

1. Zona potensial merah (red buffer zone), merupakan jarak rumah kasus malaria yang paling berdekatan dengan tempat habitat larva nyamuk Anopheles sp dengan radius 0 - 100 meter.

2. Zona potensial kuning (yellow buffer zone), merupakan jarak rumah kasus malaria yang agak jauh dengan tempat habitat larva nyamuk Anopheles sp dengan radius 100 - 200 meter.

3. Zona potensial hijau (green buffer zone), merupakan jarak rumah kasus kejadian malaria yang relatif jauh dari tempat habitat larva nyamuk Anopheles sp dengan radius 200 - 300 meter.

Data titik koordinat rumah penderita malaria dan habitat Anopheles sp serta kondisi lingkungan fisik dan kimia habitat Anopheles sp yang disurvei menggunakan alat Global Positioning System (GPS) diolah dengan menggunakan bantuan program Arcgis 9.3. Untuk menganalisa pengaruh densitas plasmodium sp terhadap anemia, trombositopenia dan SGPT/SGOT menggunakan statistik uji Chi square, kemudian disajikan dalam bentuk peta, tabel dan narasi.

\section{HASIL}

Penyebaran kasus malaria berdasarkan jenis Plasmodium di Kabupaten Kepulauan Talaud dapat dilihat pada Gambar 1. 
Jurnal Kesehatan Lingkungan

Vol.10, No.1, April 2020, pp. $33-44$

ISSN 2615-188X(Online), ISSN 2089 - 0451(Print)

Journal homepage: https://ejurnal.poltekkes-manado.ac.id/index.php/jkl

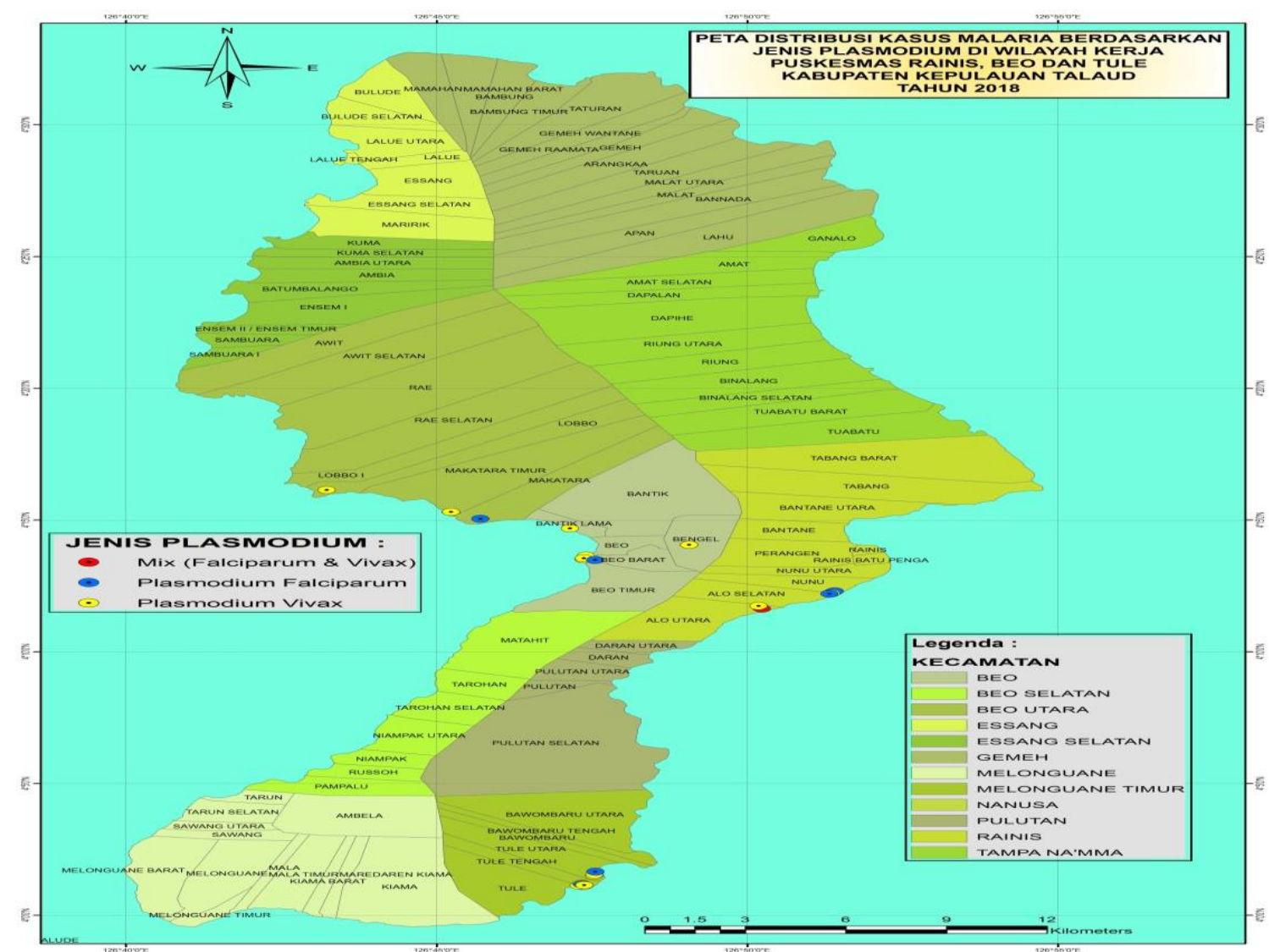

Gambar 1. Peta penyebaran kejadian malaria berdasarkan jenis Plasmodium di Kabupaten Kepulauan Talaud Tahun 2018

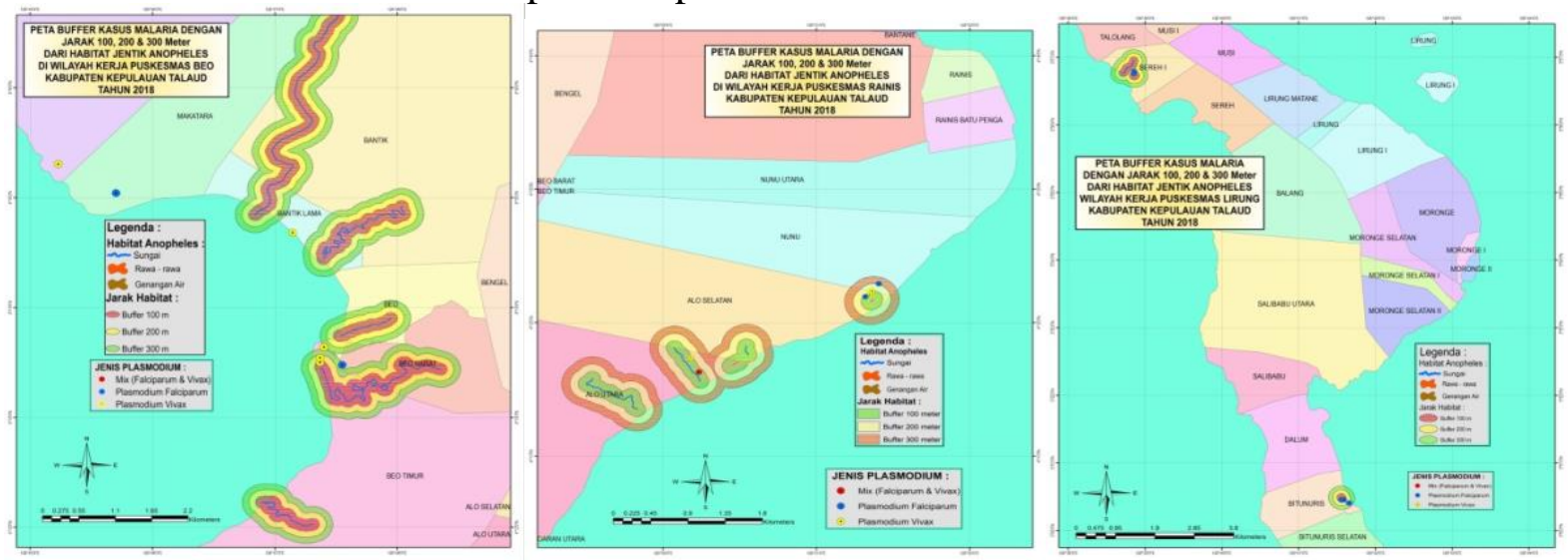



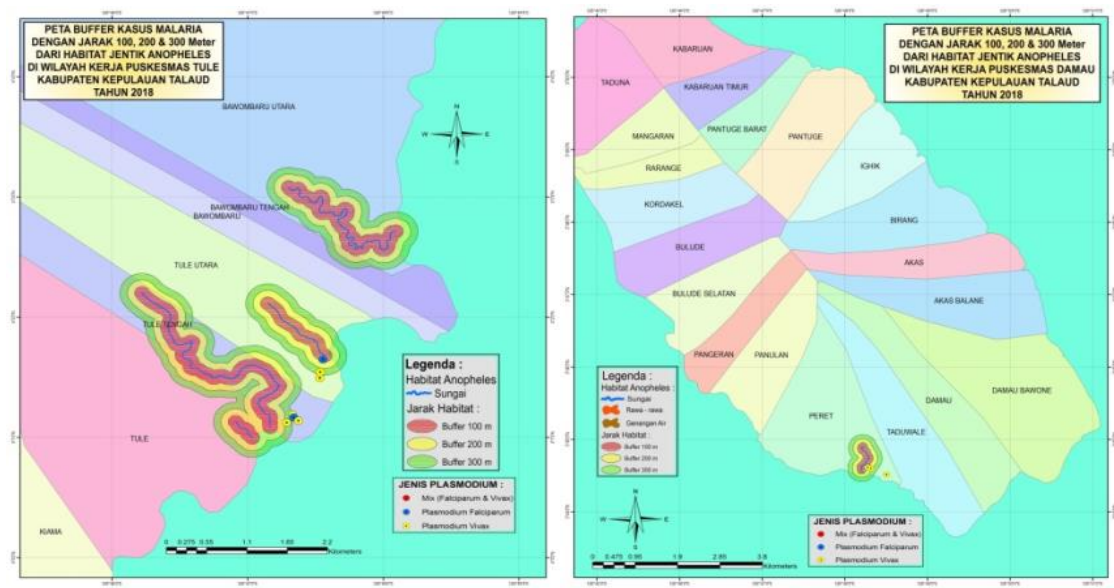

Gambar 2. Peta jarak habitat Anopheles sp dengan rumah kasus/penderita malaria di Kabupaten Kepulauan Talaud Tahun 2018.

Gambar 2. menunjukan penyebaran kasus malaria di Kabupaten Kepulauan Talaud Tahun 2018 yang berjumlah 34 kasus yang tersebar pada 5 wilayah kerja puskesmas yang menjadi lokasi penelitian. Kasus terbanyak terdapat pada wilayah kerja Puskesmas Beo yaitu 9 penderita. Dari 34 penderita yang menjadi sampel terdapat 13 penderita yang positif Plasmodium falciparum, 20 penderita positif Plasmodium vivax dan 1 penderita positif mix Plasmodium falciparum dan Plasmodium vivax.

Jenis habitat yang didapatkan jentik Anopheles sp yang berada di daerah lokasi kasus malaria di Kabupaten Kepulauan Talaud Tahun 2018 terdiri dari rawa-rawa genangan dan sungai. Jarak dari lokasi kasus bervariasi. Dari Gambar 3. Dapat dilihat bahwa dari 34 kasus malaria yang ada di Kabupaten Kepulauan Talaud, Terdapat 14 kasus berada di zona merah (red buffer zone) 3 kasus berada di zona kuning (yellow buffer zone) dan 6 kasus berada di zona hijau (green buffer zone) serta 11 kasus berada di luar zona potensial.

Kondisi lingkungan fisik (Suhu dan kelembaban) serta lingkungan kimia ( $\mathrm{pH}$ dan Salinitas) pada habitat Anopheles sp. di daerah pemukiman penderita malaria Di Kabupaten Kepulauan Talaud Tahun 2018 adalah Suhu 27.9 - 29.8 oc, kelembaban $70.5 \%-80.4 \%, \mathrm{pH}$ berada di kisaran 5.6 8.1 dan salinitas $0.04-1.35 \%$.. Seperti pada tabel 1 .

Tabel 1. Kondisi lingkungan fisik (Suhu dan kelembaban) serta lingkungan kimia (pH dan Salinitas) pada habitat Anopheles sp. di daerah pemukiman penderita malaria di Kabupaten Kepulauan Talaud Tahun 2018.

\begin{tabular}{lcccc}
\hline & \multicolumn{2}{c}{ Lingkungan Fisik (Rata-rata) } & \multicolumn{2}{c}{ Lingkungan Kimia (Rata-rata) } \\
\multicolumn{1}{c}{ Jenis Habitat } & Suhu (oc) & Kelembaban $(\%)$ & $\mathrm{pH}$ & Salinitas (gram/kg) \%o \\
\hline Rawa-rawa & 27.9 & 72 & 5.9 & 0.41 \\
Genangan & 28 & 80.4 & 8.1 & 0.04 \\
Sungai & 29.8 & 70.5 & 5.6 & 1.35 \\
& & & & \\
\hline
\end{tabular}


Pemeriksaan Malaria Secara Mikroskopis

a. Distribusi Malaria Berdasarkan Jenis Plasmodium

Distribusi malaria pada 34 penderita yang terinfeksi parasit malaria di Kabupaten
Kepulauan Talaud berdasarkan jenis plasmodium yang ditemukan terdapat dua jenis plasmodium dengan Plasmodium yang paling banyak ditemukan adalah Plasmodium viva yaitu pada 20 penderita $(58.82 \%)$ seperti pada tabel 2

Tabel 2. Distribusi Malaria Berdasarkan Jenis Plasmodium di Kabupaten Kepulauan Talaud

\begin{tabular}{lcc}
\hline \multicolumn{1}{c}{ Jenis Plasmodium } & Jumlah & $(\%)$ \\
\hline P. falciparum & 13 & 38.24 \\
P. vivax & 20 & 58.82 \\
P. malariae & 0 & 0 \\
P. ovale & 0 & 0 \\
Mix Plasmodium & 1 & 2.94 \\
\hline \multicolumn{1}{c}{ Total } & 34 & 100 \\
\hline
\end{tabular}

b. Kepadatan Plasmodium

Dari 34 sampel yang positif plasmodium dan dilanjutkan dengan menghitung kepadatan diperoleh hasil paling banyak adalah + dengan jumlah 18 penderita (52.94\%).dapat dilihat pada Tabel 3.

Tabel 3. Kepadatan Plasmodium pada penderita malaria di Kabupaten Minahasa Tenggara

\begin{tabular}{ccc}
\hline Kepadatan Plasmodium & Jumlah & $(\%)$ \\
\hline+ & 18 & 52.94 \\
++ & 10 & 29.41 \\
+++ & 5 & 14.71 \\
++++ & 1 & 2.94 \\
Total & 34 & 100 \\
\hline
\end{tabular}

Pengaruh kepadatan Plasmodium sp terhadap Anemia pada penderita malaria

Hasil pemeriksaan hemoglobin pada penderita yang terinfeksi parasit malaria di Kabupaten Kepulauan Talaud. Dari 34 penderita malaria 24 penderita (70.6\%) mengalami anemia karena kadar hemoglobin darah berada di bawah normal. Selengkapnya dapat dilihat pada Tabel 4.

Tabel 4 Hasil Pemeriksaan Hemoglobin Penderita Malaria

\begin{tabular}{ccc}
\hline Hasil Jumlah & $(\%)$ \\
\hline
\end{tabular}

\begin{tabular}{ccc}
\hline Pemeriksaan $\mathrm{Hb}$ & & \\
\hline Normal & 10 & 29.4 \\
Anemia & 24 & 70.6 \\
Total & 34 & 100 \\
\hline
\end{tabular}

Hasil Uji Statistik pengaruh kepadatan Plasmodium sp terhadap anemia pada penderita malaria di Kabupaten Kepulauan Talaud Tahun 2018 dengan menggunakan uji Chi-Square menunjukkan ada hubungan dengan $p=0.041$

Pengaruh kepadatan Plasmodium sp terhadap trombositopenia pada penderita 
malaria.

Tabel6.Trombositopenia Penderita Malaria

\begin{tabular}{ccc}
\hline \multicolumn{1}{c}{ Trombositopenia } & Jumlah & $\%$ \\
\hline \multicolumn{1}{c}{ Trombositopenia } & 24 & 70.6 \\
\hline Non trombositopenia & 10 & 29.4 \\
\hline Jumlah & 34 & 100 \\
\hline Hasil Uji Statistik & pengaruh \\
kepadatan Plasmodium sp & terhadap \\
trombositopenia pada penderita malaria di \\
$\begin{array}{l}\text { Kabupaten Kepulauan Talaud Tahun 2017 } \\
\text { dengan menggunakan uji Chi-Square } \\
\text { menunjukkan adanya hubungan } \\
p=0.041\end{array}$
\end{tabular}

\section{PEMBAHASAN}

Berdasarkan hasil pengamatan sistem informasi geografis dengan menggunakan pengolah data Arc GIS 9.3, diketahui bahwa penyebaran kasus malaria dengan positif Plasmodium berjumlah 34 kasus yang tersebar pada 5 wilayah kerja puskesmas yang menjadi lokasi penelitian dengan komposisi berbeda. Kasus terbanyak terdapat pada wilayah kerja Puskesmas Beo yaitu 9 penderita Jarak habitat larva Anopheles dengan rumah kasus menggunakan 3 jenis buffer (100 meter, 200 meter dan 300 meter) terdapat 11 kasus dari 34 kasus malaria yang berada di luar zona potensial. Zona merah (red buffer zone) dengan radius 0-100 meter merupakan jarak rumah kasus paling dekat dengan tempat habitat yaitu sebanyak 14 kasus, zona kuning (yellow buffer zone) dengan radius 101-200 meter merupakan rumah kasus malaria agak jauh dengan tempat habitat yaitu sebanyak 3 kasus dan zona hijau (green buffer zone) dengan radius 1001-1500 meter merupakan rumah kasus malaria relatif jauh dari tempat habitat yaitu 6 rumah kasus.
Achmadi (2013) menyatakan bahwa jarak terbang nyamuk betina Anopheles $s p$ dapat terbang dengan jarak 500 - 1500 Meter dari habitat jentik/larva sedangkan menurut Peterson, et al. (2009) hasil penelitian di Adama, Ethiopia menunjukan jarak habitat larva Anopheles dengan rumah kasus < 350 meter didapati kejadian malaria sebesar 684,8 per seribu penduduk sedangkan dengan jarak > 350 meter didapati kejadian malaria sebesar 65,7 per seribu penduduk.

Berdasarkan hasil buffering dapat diketahui prioritas wilayah yang perlu dilakukan suatu perencanaan intervensi pengendalian penyakit malaria, seperti penentuan prioritas lokasi penyuluhan kesehatan dan lokasi pemberantasan vektor malaria.

Berdasarkan hasil penelitian yang dilakukan di Kabupaten Kepulauan Talaud bahwa suhu breeding places berkisar 27.9 - 29.8 oc. suhu breeding places yang paling tinggi yaitu pada suhu $29.8^{\circ} \mathrm{C}$ terdapat pada sungai, Hal ini sejalan dengan penelitian Hidayani (2011) memperoleh hasil pengukuran suhu berada pada kisaran $26^{\circ} \mathrm{C}-29^{\circ} \mathrm{C}$. Ini merupakan suhu yang sangat ideal bagi kehidupan larva Anopheles pada jenis Breeding Places manapun dengan kondisi yang bervariasi. Hal ini sejalan dengan hasil penelitian dari Takken dkk., (2008) dalam Santjaka, (2013) mengatakan bahwa suhu micro berkisar $20^{\circ} \mathrm{C}-35^{\circ} \mathrm{C}$, dan Nurhayati HL. dkk, dalam penelitiannya berada pada kisaran dengan suhu berkisar antara 25 $31^{\circ} \mathrm{C}$ yang tingkat kepadatan larva tertinggi berada pada suhu $31^{\circ} \mathrm{C}$. Suhu air dipengaruhi oleh suhu lingkungan dan paparan sinar matahari pada breeding places. Sedangkan menurut Kemenkes RI (2013) suhu optimum untuk tempat perindukan nyamuk berkisar antara 25 $27^{\circ} \mathrm{C}$. 
Adanya perbedaan suhu breeding places yang ditemukan oleh peneliti dikarenakan adanya perbedaan kondisi geografi dimana ada tempat perkembangbiakan yang memiliki tanaman pelindung disekitar breeding places dan ada juga yang tidak mempunyai tanaman pelindung sehingga memungkinkan terjadinya penyinaran matahari. Dan secara langsung juga dikarenakan oleh perbedaan musim serta waktu pengukuran suhu.

Berdasarkan hasil penelitian menunjukkan bahwa $\mathrm{pH}$ pada breeding places berkisar antara 5.6 - 8.1. $\mathrm{pH}$ breeding places yang paling tinggi yaitu 8.1 yang terdapat pada genangan. Menurut Takken dan Knols (2011) lingkungan kimia diketahui sangat besar pengaruhnya pada populasi vektor malaria, hal ini disebabkan oleh spesies nyamuk yang dapat hidup pada $\mathrm{pH}$ yang berbeda misalnya An. letifer bisa bertahan hidup di lingkungan air tawar ( $\mathrm{pH}$ rendah/asam). Hal ini sejalan dengan penelitian Syarif, 2003 dalam Rahman. R.R. dkk, larva Anopheles memiliki toleransi terhadap $\mathrm{pH}$ antara 7,91 - 8,09. Raharjo dkk, 2003 dalam Rahman. R.R. dkk, juga menyatakan bahwa $\mathrm{pH}$ tempat perindukan nyamuk Anopheles pada musim kemarau berkisar antara 6,8-8,6.

Salinitas merupakan kadar garam yang terkandung didalam air tawar, air payau maupun air asin yang dapat mempengaruhi pertumbuhan jentik/larva. Berdasarkan hasil pengukuran pada breeding places diperoleh salinitas berkisar $0.04-1.35$ \%. Berdasarkan teori Mulyadi (2010) bahwa larva Anopheles biasanya hidup dengan salinitas $0 \%$ pada air tawar dan $0-7 \%$ pada air payau. Selain itu tempat perkembangbiakan nyamuk Anopheles sp pada ekologi pantai yang cenderung mempunyai air bersifat payau juga menjadi kesenangan dari nyamuk $A n$. subpictus. Hal ini sejalan dengan hasil penelitian Mading (2010) pada daerah pantai di Desa Selong Belanak Kabupaten Lombok Tengah yang menemukan delapan jenis breeding places yang salinitasnya berkisar $0-14 \%$. Menurut Kemenkes RI (2013), bahwa jentik/larva tumbuh optimal pada air payau yang kadar garamnya berkisar $0-18 \%$ dan tidak dapat berkembang biak pada garam lebih dari $40 \%$.

hasil pemeriksaan kepadatan jumlah Plasmodium pada penderita malaria di Kota Bitung pada bulan April - Agustus 2018 yaitu dari 34 responden yang diteliti terdapat 18 orang responden dengan jumlah kepadatan (+) dan 10 orang responden dengan jumlah kepadatan $(++) 5$ responden $(+++)$ dan 1 responden $(++++)$. Sehingga dapat disimpulkan bahwa jumlah tertinggi kepadatan plasmodium yaitu (+). Dalam penelitian Made I.P Paramita hal ini sesuai dengan penelitian yang dilakukan Dwithania, dkk di Puskesmas Durian dan Puskesmas Talawi Kota Sawahlunto, dimana dari hasil hitung parasit (parasite count) didapatkan semua insiden malaria tergolong derajat infeksi ringan (100\%). Hasil penelitian ini menunjukkan bahwa masyarakat di daerah endemik sudah lebih memperhatikan kesehatannya dan segera berobat ke Puskesmas ataupun ke Rumah Sakit terdekat pada gejala awal penyakit sehingga kasus malaria dapat terdeteksi sejak serangan awal. Disamping itu pada serangan awal, jumlah parasit yang berada di darah tepi masih sedikit sehingga kepadatan parasit masih rendah. Sesuai data yang didapat dari Dinas Kesehatan Kabupaten Kepulauan Talaud kebanyakan dari penderita malaria jumlah kepadatan yang didapatkan pada tahun 2016 sampai pertengahan 2018 yaitu jumlah kepadatannya paling banyak (+) dikarenakan Kabupaten Kepulauan Talaud 
dulunya merupakan salah satu daerah endemik malaria di Sulawesi Utara walaupun hanya diposisi peringkat ke-3 dengan persentase antara peringkat pertama dan kedua sangat jauh berbeda persentasenya. Sekarang ini masyarakat sudah lebih memperhatikan masalah kesehatannya dengan segera berobat ke rumah sakit dan puskesmas terdekat bila sudah ada tanda atau gejala yang timbul sehingga kasus malaria terdeteksi sedara awal. Disamping itu serangan awal jumlah parasit yang berada di darah tepi masih sedikit sehingga kepadatan parasit masih rendah.

Penderita malaria terbanyak adalah penderita dengan umur $15-54$ tahun sebanyak 25 orang $(73.53 \%)$ yang merupakan golongan usia dewasa. Hasil penelitian ini tidak jauh berbeda dengan penelitian yang dilakukan oleh Munizar dkk (2015) di Kecamatan Seulimum Aceh Besar dan penelitian oleh Radiati (2002) di Tasikmalaya yang menyatakan bahwa responden yang menderita malaria lebih banyak pada kelompok umur dewasa dibandingkan dengan kelompok umur yang belum dewasa, hal ini disebabkan karena kelompok umur ini merupakan kelompok usia produktif ( 15 - 54 tahun) dimana pada usia tersebut memungkinkan untuk bekerja dan bepergian keluar rumah sehingga lebih berpeluang untuk kontak dengan vektor penyakit malaria.

Karakteristik penderita malaria berdasarkan jenis kelamin, menunjukkan penderita malaria berjenis kelamin lakilaki sebanyak 21 orang $(61.76 \%)$ dan perempuan sebanyak 13 orang (38.24\%). Menurut Kemenkes (2013) infeksi malaria tidak membedakan jenis kelamin akan tetapi bila menginfeksi ibu hamil akan menyebabkan anemia yang lebih berat. Perbedaan prevalensi menurut umur dan jenis kelamin berkaitan dengan derajat kekebalan karena variasi keterpaparan gigitan nyamuk (Winardi, 2004 dalam Sulistiyani, 2012).

Anemia atau penurunan kadar hemoglobin darah sampai di bawah nilai normal pada penyakit malaria disebabkan penghancuran sel darah merah yang berlebihan oleh parasit malaria (Sucipto, 2015). Anemia merupakan salah satu komplikasi yang terlihat pada malaria. Telah dilaporkan bahwa sebagian besar penyebab kematian pada malaria disebabkan oleh tingkat atau derajat keparahan anemia (Akinbo dkk, 2009). Berdasarkan hasil pemeriksaan kadar hemoglobin 34 responden, 10 responden dengan kadar hemoglobin normal dan 24 responden dengan kadar hemoglobin di bawah nilai normal yang menunjukkan penderita mengalami anemia. Hasil Uji Statistik pengaruh kepadatan Plasmodium sp terhadap anemia pada penderita malaria di Kabupaten Kepulauan Talaud Tahun 2018 dengan menggunakan uji Chi-Square menunjukkan ada hubungan yang signfikan dengan $p=0.041$

Parasit malaria berada dalam darah pada sebagian besar siklus hidupnya sehingga menginduksi perubahan dalam darah. Malaria mempengaruhi hampir seluruh komponen darah. Abnormalitas darah sehubungan dengan infeksi malaria antara lain anemia, trombositopenia, splenomegali, limfositosis ringan hingga berat serta (dalam kasus yang jarang) Disseminated Intravascular Coagulation (DIC). (Natalia, 2014)

Meskipun malaria merupakan infeksi pada eritrosit, patofisiologi utama dalam perkembangan malaria berat adalah interaksi antara sel terinfeksi dan endotelium mikrovaskular, dimana Trombosit dan produk aktivasinya terlibat dalam sekuestrasi eritrosit terinfeksi ke endotel kapiler dan vena. (Ivanna, 2013) 
Hasil uji statistik menunjukkan bahwa $\mathrm{Ha}$ diterima, menunjukkan adanya hubungan antara jenis kepadatan plasmodium dengan jumlah trombosit $(p=$ 0.041).

Hasil tersebut didukung dengan penelitian yang dilakukan Jojera dkk pada tahun 2013 di India, dimana ditemukan lebih dari $80 \%$ penderita malaria baik infeksi p.falciparum maupun p.vivax mengalami penurunan jumlah trombosit dan $92,48 \%$ kasus ditemukan pada infeksi P. falciparum.

Trombositopenia juga ditemukan pada penderita dengan malaria vivax, pada penelitian ini ditemukan 20 penderita malaria vivax dengan komplikasi malaria yang bervariasi.. Penelitian oleh Koltas dkk menyatakan trombositopenia dapat dijadikan penunjang dalam menegakkan diagnosis malaria vivax.

Penyakit malaria dapat disebabkan oleh infeksi salah satu jenis Plasmodium ataupun mix infection yang merupakan infeksi gabungan dua atau lebih (jarang) spesies Plasmodium. Dalam penelitian ini ditemukan 1 penderita dengan mix infection (Plasmodium falciparum dan plasmodium vivax) hal ini dapat memungkinkan keparahan dan komplikasi dapat terjadi.

Berkurangnya peredaran trombosit di sirkulasi pada malaria juga diasumsikan akibat mekanisme dimediasi antibodi. Terjadi peningkatan antibodi antiplatelet IgG pada penderita malaria (baik falciparum maupun vivax) yang mengaktivasi membran trombosit, yang menyebabkan pembuangan trombosit oleh sistem retikuloendotelial, khususnya pada limpa. Dalam limpa, trombosit diduga difagosit oleh makrofag teraktivasi. (Abdalla, 2004).

\section{KESIMPULAN}

Penyebaran kejadian malaria dan Jarak habitat Anopheles sp dengan rumah penderita malaria di Kabupaten Kepulauan Talaud Tahun 2018 terspasialkan. Kondisi lingkungan fisik (Suhu dan kelembaban) serta lingkungan kimia ( $\mathrm{pH}$ dan Salinitas) pada habitat Anopheles sp. di daerah pemukiman penderita malaria adalah Suhu 27.9 - 29.8 oc, kelembaban $70.5 \%$ - 80.4\%, pH berada di kisaran 5.6 - 8.1 dan salinitas 0.04 - $1.35 \%$. Densitas Plasmodium sp pada 34 penderita malaria terdiri dari 18 kasus +, 10 kasus ++, 5 kasus +++ dan 1 kasus ++++. Hasil uji statistik ada hubungan antara kepadatan Plasmodium sp terhadap anemia dan trombositopenia pada penderita malaria di $\mathrm{Di}$ Kabupaten Kepulauan Talaud Tahun 2018.

\section{SARAN}

1. Untuk masyarakat agar supaya memperhatikan dan meningkatkan kesadaran akan hal-hal apa saja yang dapat menyebabkan terjadinya malaria dan melakukan kegiatan pencegahan malaria seperti pembersihan lingkungan secara rutin minimal 1 minggu sekali

2. Kepada instansi terkait yaitu Dinas Kesehatan Kabupaten Kepulauan Talaud perlu melakukan pemetaan kasus malaria dengan sistim buffering guna mengetahui pola penyebaran penyakit malaria sehingga pengendalian vektor malaria tepat pada sasaran.

3. Penanganan/pengobatan penderita malaria jangan hanya terfokus pada parasitnya tapi harus disertai juga dengan pengobatan pada gejala klinis yang dialami oleh penderita yaitu Anemia, Trombositopenia.

4. Perlu dilakukan penelitian pemetaan malaria di seluruh kabupaten/kota yang ada di Provinsi Sulawesi Utara.

\section{DAFTAR PUSTAKA}


Ansari, S., Khoharo, HK., Abro, A., Akhund, IA., \& Qureshi, F. (2009). Thrombocytopenia in $P$. falciparum Malaria. J Ayub Med Coll Abbottadab. 21(2):145-147.

Arsin, Andi Arsunan. 2012. Malaria di Indonesia Tinjauan Aspek Epidemiologi. Makassar: Masagena Press

Baldy, Catherine M., (2005). Gangguan Koagulasi. Di dalam: Price S., \& Wilson L. Patofisiologi: Konsep Klinis Proses-Proses Penyakit. Ed 6. EGC: Jakarta.

Boewono, D.T., \& Ristiyanto, 2004, Studi Bioekologi Malaria di Kecamatan Srumbung Kabupaten Magelang, Jawa Tengah, Balai Penelitian Vektor dan Reservoir Penyakit, Badan Litbangkes.

Beaty, B.J., \& Marquardt, W.C, 1996, The Biology Of Desease Vectors, Published by University Press Of Colorado.

Danoedoro, P., 2004, Sains Informasi Geografis, dari Perolehan dan Analisis Citra hingga Pemetaan dan Pemodelan Spasial, Jurusan Kartografi dan Penginderaan Jauh Fakultas Geografi UGM, Yogyakarta.

Dinkesda Provinsi Sulut. (2017). Profil Kesehatan Daerah 2016. Dinas Kesehatan Provinsi Sulawesi Utara.

Harijanto, P. N. (2012). Gejala Klinis Malaria Ringan. dalam Harijanto, P. N., Nugroho, A. \& Gunawan, C. A. Malaria dari Molekuler ke Klinis. Edisi II. Penerbit Buku Kedokteran EGC, Jakarta.

Harijanto, P.N., Nugroho, A., \& Gunawan, CA., (2010). Malaria: dari Molekuler ke Klinis: Edisi 2. EGC: Jakarta.

Ishak, H., Wahid, I., Saleh, M., (2009). Distribusi Spatial Vektor Malaria, Ekobionomik Dan Prevalensi Malaria
Di Sulawesi Barat. Lembaga Penelitian Universitas Hasanuddin Makassar.

Jojera, A.S., Hathila, R.N., Patel, P.R. \& Tailor, HJ. (2013). Changes in WBC and Platelets Count in Patients with Malaria: A Hospital Based Comparative Study. Int J Res Med Sci. Vol 1. Issue 4: 401-403.

Kemenkes RI. (2013) Profil Pengendalian Penyakit dan Penyehatan Lingkungan Tahun 2012. Dirjen PP \& PL.

Kemenkes RI. (2013). Riset Kesehatan Dasar; RISKESDAS Jakarta: Balitbang Kemenkes RI

Kemenkes RI. (2018). Profil Kesehatan Indonesia 2017.

Mexitalia, M., Nurjaya, I. G. K. O., Saptanto, A., Tamam, M., Hartantyo, I. \& Soemantri, A. (2007). Status Gizi, Eosinofilia dan Kepadatan Parasit Malaria Anak Sekolah Dasar di Daerah Endemis Malaria. Sari Pediatri. Vol, 9, No. 4: 274-280.

Natalia, Diana. (2014). Peranan Trombosit dalam Patogenesis Malaria. Jurnal MKA: Kalimantan Barat. Vol 37. No 3: 219-244.

Peterson, I., Borrell, L.N., El-Sadr, W, \& Teklehaimanot, A., 2009, A Temporal-Spatial Analysis of Malaria Transmition in Adama, Ethiopia, $J$. Trop. Med. Hyg., 81(6) : 944-949.

Prodjodipuro P, Sutamihardja, A., Sumawinata, IW., Masbar, S., Wangsamuda, S., \& Maguire, JD. (2004). Buku Panduan Pelatihan Diagnosa Mikroskopi Malaria. Departemen Parasitologi Medis. US NAMRU-2: Jakarta.

Rosida, A. 2016. Pemeriksaan Laboratorium Penyakit Hati. Badan Patologi Klinik Fakultas Kedokteran Universitas Lambung Mangkurat. (hal.129) 
Soedarto. (2011). Malaria. Sagung Seto: Jakarta.

Soenarmo, 2009, Penginderaan Jauh dan Pengenalan Sistem Informasi Geografis Untuk Bidang Ilmu Kebumian, Bandung, Institut Teknologi Bandung.

Sucipto, C.D. 2014. Manual Lengkap Malaria. Gosyen Publishing. Semarang

Suparman Eddy, Suryawan Aloysius. (2004). Malaria pada Kehamilan. Volume 4. Nomor 1
Susilawati, Sennang, N., Naid, T. \& Attamimi, F. (2013). Kadar Hemoglobin dan Densitas Parasit pada Penderita Malaria di Lombok Tengah. JST Kesehatan, Vol. 3, No. 3: 298-304.

Sutisna Putu, (2004). Malaria : Secara Ringkas Dari Pengetahuan dasar sampai Terapan. Jakarta: Penerbit Buku Kedokteran EGC 